\title{
Literature Review : The Application of Soak Feet Warm Water Therapy on Decrease Blood Preassure in Elderly With Hypertension
}

\author{
$\underline{\text { Laila Tafricha Sari }{ }^{1}, \text { Yeni }_{\text {Yuliastanti }}{ }^{2}, \text { Heni Yuniarti }}{ }^{3}$ \\ tafricha81@gmail.com
}

\begin{abstract}
Background : Hypertension is a silent killer because it is a disease that does not show typical symptoms. Based on reports worldwide, an estimated 17,7 million people die of herat desease and blood vessel disease by 2025, hypertension suffers are estimated to reach 1,6 billion people (WHO, 2013). Management of hypertension is more focused on pharmacological techniques and Non-pharmacological techniques. Non-pharmacological techniques that can be used are soak feet warm water therapy in people with elderly hypertension.

Purpose : To provide a theoretical basis for research on non-pharmacological soak feet warm water therapy in elderly with hipertension sufferers.

Methods : This study uses a literature review method, the databases used are Google Scholar, PubMed, and Garba Rujukan Digital with a time limit of the last 5 years.

Results : The application of soak feet warm water therapy in elderly with hypertension sufferers has a significant effect on reducing blood preassure.

Conclusion : Giving soak feet warm water therapy has an effect on reducing blood preassure in people with elderly with hypertension
\end{abstract}

Keywords : hypertension, elderly, soak feet warm water therapy

1,2) Jurusan Keperawatan, Poltekkes Kemenkes Semarang

Jl. Perintis Kemerdekaan, Magelang Utara, Kota Magelang, Jawa Tengah, Indonesia

3) Dinas Kesehatan Kota Magelang

Jl. Jend. Sarwo Edhie Wibowo No.2, Kota Magelang, Jawa Tengah, Indonesia

Background. Hypertension is a silent killer because it is a disease that does not show typical symptoms but cause complication that lead to death. Hypertension is a global health problem, hypertension not only causes death but on the other hand the number of people with hypertension has increased in terms of time (WHO, 2013). Based on the WHO report (2013), it is estimated that 17.7 million people will die from heart and blood vessel disease in 2025 with hypertension, which is estimated to reach 1.6 billion people. The number of hypertension sufferers in Indonesia has increased quite significantly from $25.8 \%$ in 2013 and increased to $34.1 \%$ in 2018 (Riskesdas, 2018).

The management of hypertension is more focused on pharmacological and nonpharmacological management. Pharmacological methods are actually effective in lowering blood pressure, but the side effects of taking anti-hypertensive drugs must be taken into account, such as headaches, dizziness and weakness. The results of research on alternatives to treating hypertension nonpharmacologically can be done by doing a warm foot soak that can be done at any time, because the effect of foot soaking is the same as walking barefoot for 30 minutes (Yonata, 2016). Hydrotherapy (warm water) is a complementary therapy that has been shown to have a positive effect on blood pressure. The results of scientific studies show that warm water has an impact and biological factors on the body, especially in blood vessels, where warm water makes blood circulation smooth and strengthens the ligament muscles that affect the joints of the body (Harnani, 2017).

The working principle of this therapy is to use conduction warm water where heat transfer occurs from warm water to the body, so that it will dilate blood vessels and can reduce muscle tension (Harnani, 2017). The results showed a positive effect of warm foot 
soaking on blood pressure. Research conducted by Dilianti, Candrawati, \& Adi (2017) on the effect of effective hydrotherapy on reducing blood pressure in elderly people with hypertension shows that statistically after hydrotherapy for 10 minutes every morning and evening for 6 days there is a decrease in blood pressure.

This study is in line with the research of Ilkafah (2016), which concluded that warm water foot bath therapy is effective in reducing blood pressure where warm water makes blood circulation smooth. Hydrotherapy can lower blood pressure because in the work process hydrotherapy provides a relaxing effect or a sense of comfort and functions as a vasodilator for blood flow so that it can reduce blood pressure (Umah, 2014). Soaking in warm water has been shown to lower blood pressure. Based on this phenomenon, it is necessary to conduct a literature review by identifying research articles describing the effectiveness of warm water foot soaking as an alternative in lowering blood pressure in hypertensive patients.

Objective. To provide a theoretical basis for research on non-pharmacological soak feet warm water therapy in elderly with hipertension sufferers.

Methods. The method used in this study is a literature review. Inclusion criteria: research articles whose respondents are elderly people with hypertension. The time for preparing the literature review starts from December 7, 2020 to December 11, 2020. This literature method uses the Systematic Literature Review (SLR) method with the PRISMA flow. The database used by Google Scholar, Pubmed, and Digital Reference Garba with a time limit of the last 5 years.

Result and Discussion. Presenting a research article on the effect of warm water foot soaking in elderly people with hypertension. After the author does a search using the keywords soak feet in warm water, the elderly, and hypertension. When doing a search, it was obtained 25 literatures from Google Scholar. The research articles were selected by the authors of 3 research articles. Then added by searching on the Digital Reference Garba, 7 literatures were obtained. Then the authors choose 2 research articles. The following table of search results:

Changes in Blood Pressure of Hypertensive Elderly Through Foot Soak
Therapy Using Warm Water (Nur Uyuun, 2019). This study uses a quasy exsperiment design with one group pre test post test on 18 samples. The results of data analysis using the Paired T-Test statistical test obtained $p$ value $=0.001$, which means that there is an effect of foot soak therapy on blood pressure. It is recommended that foot soak therapy using warm water is carried out regularly as a companion treatment for hypertension.

The Effect of Hydrotherapy with Warm Foot Soak on Blood Pressure Levels in Elderly Patients with Hypertension in Depok Ambarketawang Gamping Hamlet, Sleman Yogyakarta (Istiqomah, 2017). This study uses a quasy experiment with pre test and post test design on 38 samples. The results showed that there were differences in warm water foot soak therapy with ordinary water foot soak therapy $(p=0.394 p>0.05$ and $p 0.000$ with $p<0.05$ ). From this study, warm water foot soak therapy was effective in reducing blood pressure in elderly people with hypertension.

Soak Feet Warm Water Therapy Effective To Reduce Blood Pressure In The Elderly (Yessi Harnani, 2017). This study uses Quasy Experiment with Pre experimental and pretestposttest design on 30 samples. The results of statistical tests showed that the average systolic blood pressure after being given warm water foot soak therapy was 74.00 and a standard deviation of 5.026 with a systolic $P$ value of $0.000(<0.05)$ and a diastolic $P$ value of $0.000(<0.05$. So it can be stated that there is a trendy effect of warm feet on lowering blood pressure.

Differences in Blood Pressure Before and After Warm Water Foot Soak Therapy for the Elderly at the Social Center for Elderly Assistance Budi Agung Kupang (Yasinta Asana, 2016). This study uses a quasy experiment with one group pra-post test design on 42 samples. The results of the systolic and diastolic blood pressure statistical tests obtained a p value of 0.000 , it can be concluded that there is a significant difference between blood pressure before and after warm water foot soak therapy. This can be used as input and information in developing forms of non-pharmacological services as a nursing intervention in overcoming hypertension in the elderly.

The Effect of Warm Water Foot Soak Therapy on Decreasing Blood Pressure in Elderly Patients with Hypertension in the 
Work Area of Upk Puskesmas Khatulistiwa Pontianak City (Santoso, 2015). This study uses a quasy experiment with pretest and posttest design on 16 samples. The results of the assessment before therapy were mostly elderly with grade I hypertension. The statistical test results with the paired t test showed that the diastolic $p$ value was 0.000 $(<0.05)$ and the Wilcoxon test results on systolic blood pressure showed that the systolic $p$ value was $0.001(<0,05)$, so $\mathrm{HO}$ is rejected. Thus, there is an effect of warm water foot soaking therapy on reducing blood pressure in elderly people with hypertension in the work area of the Khatulistiwa Health Center UPK in Pontianak City.

The findings of the five articles analyzed showed that warm foot bath was very effective in reducing blood pressure in the elderly with hypertension. Hypertension is a problem in the heart and blood vessels that causes blood pressure to rise. The average of respondents who carried out soaking feet in warm water was 60-90 years old.

One way to lower blood pressure is hydrotherapy soak in warm water. Foot soak therapy with warm water is a therapy by soaking the feet to a limit of $10-15 \mathrm{~cm}$ above the ankles using warm water. The tools and materials that must be provided are warm water, large basin, water thermometer, timer, small towel, sphygmomanometer, and stethoscope (Yessi Harnani, 2017). The effect of foot soaking using warm water can produce heat energy which dilates blood vessels and improves blood circulation as well as stimulating the nerves in the feet to activate the parasympathetic nerves, causing changes in blood pressure.

The working principle of this therapy is to use warm water with a temperature of $38-40^{\circ} \mathrm{C}$ for 20-30 minutes in conduction where there is a transfer of heat from warm water to the body so that it will cause dilation of blood vessels which results in increased blood circulation. Physiologically, the body's response to heat is to cause the widening of blood vessels, reduce blood viscosity, reduce muscle tension, increase tissue metabolism and increase capillary permeability (Istiqomah, 2017). If done with the intensity of time given continuously, it can lower blood pressure. In line with the research of Yasinta Asana (2016) said that after giving warm water foot soak therapy, there was a decrease in systolic blood pressure, namely $<140 \mathrm{mmHg}$ as many as 38 elderly (90\%). The average range for the reduction in blood pressure was $10-39 \mathrm{mmHg}$, while the diastolic blood pressure decreased, namely $<90 \mathrm{mmHg}$ by 38 respondents $(90 \%)$. The mean range for the reduction in blood pressure is $20-28 \mathrm{mmHg}$. Santoso's study (2015) experienced a decrease in systolic blood pressure to $20 \mathrm{mmHg}$ and diastolic blood pressure to $10 \mathrm{mmHg}$. Meanwhile, Yessi Harnani's research (2017) has decreased systolic blood pressure up to $14 \mathrm{mmHg}$ and diastolic blood pressure up to $7 \mathrm{mmHg}$.

The frequency and duration of warm foot soaking is closely related to a decrease in blood pressure in hypertension. The frequency of 1 time for 7 days of giving a warm foot soak for 20 minutes can lower blood pressure. Meanwhile, Yessi Harnani's (2017) research frequency of 1 time for 3 days of giving warm water foot soaks for 25-30 minutes. Meanwhile, according to Santoso (2015), foot soaking in warm water with one meeting for 20 minutes can also reduce blood pressure in elderly people with hypertension.

Conclusion and Suggestions. The Conclusion is the 5 articles that have been reviewed by the author in a literature review study about soaking feet using warm water in elderly people with hypertension have a significant effect on reducing blood pressure. The results of this Literature Review recommend warm foot bath as a nonpharmacological treatment of choice that can affect both elderly people with hypertension at home and in the hospital.

Acknowledgements. Thanks to the researchers say to all those who have helped in completing this research.

\section{References}

Harnani, Y. (2017) Efektifitas Rendam Kaki Menggunakan Air Hangat Terhadap Penurunan Tekanan Darah pada Lansia Diwilayah Kerja Puskesmas Simpang Tiga Kota Pekanbaru Tahun 2016. Jurnal Kesehatan Komunitas, 3 (4), 129-132

Ilkafah. (2016). Perbedaan penurunan tekanan darah lansia dengan obat anti hipertensi dan terapi rendam air hangat di wilayah kerja Puskesmas Antara Tamalanrea. Jurnal IImiah Farmasi UNSRAT Vol. 5 (No. 2), Edisi Mei. ISSN: 2302-2493. 
Makasar

Istiqomah. (2017). Pengaruh Hidroterapi

Rendam Kaki Air Hangat Terhadap

Tingkatan Tekanan Darah Pada Lansia Penderita Hipertensi Di Dusun Depok Ambarketawang Gamping Sleman Yogyakarta. Universitas 'Aisyiyah Yogyakarta .

Nur Uyuun, S. M. (2019). Perubahan Tekanan Darah Lansia Hipertensi Melalui Terapi Rendam Kaki Menggunakan Air Hangat.

Santoso, D. A. (2015). Pengaruh Terapi Rendam Kaki Air Hangat Terhadap Penurunan Tekanan Darah Pada Lansia Penderita Hipertensi Di Wilayah Kerja Upk Puskesmas Khatulistiwa Kota
Pontianak. Universitas Tanjungpura Pontianak.

Yasinta Asana, M. S. (2016). Perbedaan Tekanan Darah Sebelum Dan Sesudah Terapi Rendam Kaki Air Hangat Pada Lansia Di Upt Panti Sosial Penyantunan Lanjut Usia Budi Agung Kupang. CHM-K Health Journal .

Yessi Harnani, A. A. (2017). Soak Feet Warm Water Therapy Effective to Reduce Blood Pressure In The Elderly. Jurnal Kesehatan Komunitas, 129-132.

Yonata, A., \& Pratama, A. S. P. (2016). Aktifitas Fisik Pada pasien Hipertensi. Jurnal Majority, 5 (3), 17-21. 